EKONOMIKAWAN : Jurnal Ilmu Ekonomi dan Studi Pembangunan

ISSN : $1693-7600$ (Print), ISSN : 2598-0157 (Online), http://jurnal.umsu.ac.ld/index.php/ekawan

\title{
Pengaruh Aktivitas Industri Terhadap Pertumbuhan Ekonomi di Kabupaten Karo
}

\section{Lasma Melinda Siahaan}

Fakultas Ekonomi Universitas Quality

Jl. Ngumban Surbakti No.18, Sempakata, Kec. Medan Selayang,

Kota Medan, Sumatera Utara 20132

e-mail : lasmamelindasiahaan@yahoo.co.id

\begin{abstract}
ABSTRAK
Penelitian ini bertujuan untuk mengetahui bagaimana pengaruh aktivitas industri terhadap pertumbuhan ekonomi di Karo. Metode yang digunakan dalam penelitian ini adalah Analisis Regresi Linier Sederhana dengan menggunakan program SPSS24. Data yang digunakan dalam penelitian ini adalah data deret waktu 2010-2016. Hasil regresi menunjukkan jumlah perusahaan industri memiliki pengaruh yang signifikan dan positif terhadap pertumbuhan ekonomi di kabupaten Karo.
\end{abstract}

Kata kunci: Kegiatan Industri, Pertumbuhan Ekonomi, Kabupaten Karo 


\title{
Effect of Industrial Activities on Economic Growth in Karo Regency
}

\begin{abstract}
This research aims to determine how the influence of industrial activity on economic growth in Karo regency. The method used in this research is Simple Linear Regression Analysis using program SPSS24. Data used in this research is time series data from 2010-2016. The regression results show the number of industrial companies has a significant and positive influence on economic growth in Karo regency.
\end{abstract}

Keywords: Industrial Activities, Economic Growth, Karo Regency

\section{PENDAHULUAN}

Munculnya pembangunan suatu industri menjadi bentuk salah satu upaya manusia guna meningkatkan kualitas hidupnya. Hal ini dikarenakan tujuan adanya pembangunan industri adalah untuk menciptakan lapangan pekerjaan, mendukung pemerataan pembangunan, peningkatan pendapatan dan kesejahteraan hidup.

"Sektor industri dipercaya mampu menjadi sektor yang memimpin sektor lainnya dalam perekonomian suatu negara. Barang dan jasa yang dihasilkan dari sektor industri cenderung memiliki nilai tambah yang lebih besar dan menguntungkan bila dibandingkan dengan barang dan jasa dari sektor lainnya" (Pasaribu, Rowland B. F. 2012).

"Hal ini disebabkan karena sektor industri memiliki produk yang sangat beragam dan mampu memberikan manfaat marjinal yang tinggi kepada pemakainya serta memberikan marjin/keuntungan yang lebih menarik. Oleh sebab itu industrialisasi dianggap sebagai 'obat mujarab' (panacea) untuk mengatasi masalah pembangunan ekonomi di negara berkembang" (Pasaribu, 2012).

Menurut Alfian dalam Syaifullah, 2009 : "memberikan uraian mengenai berbagai ekses atau dampak industrialisasi yang terjadi dalam masyarakat di antaranya: ditinjau dari sudut ekonomi, keberhasilan tentunya akan menyebabkan perubahan yang amat berarti dalam struktur perekonomian masyarakat."

Adanya pembangunan industri tentunya memberikan dampak terhadap perubahan struktur sosial masyarakat. Kehidupan sebagian besar masyarakat akan bergantung pada sektor industri. Sedangkan jika dilihat dari segi budaya, industrialiasi akan berdampak terjadinya perubahan nilai dan gaya hidup masyarakat yang lebih bergantung pada produk hasil industri.

Ditinjau dari dampak yang ditimbulkan dari adanya pembangunan industri tentunya membutuhkan kajian lebih rinci untuk menganalisisnya. Keberadaan industri disatu sisi dapat memberikan dampak positif dan negatif baik kepada manusia maupun lingkungan sekitarnya. "Dampak positif dan negatif dari keberadaan industri akan menimbulkan perubahan bagi masyarakat sekitar industri tersebut baik kondisi sosial ekonomi maupun kondisi budaya"(Nawawi, dkk, 2014). 
Published July 2019

EKONOMIKAWAN : Jurnal Ilmu Ekonomi dan Studi Pembangunan

ISSN : $1693-7600$ (Print), ISSN : 2598-0157 (Online), http://jurnal.umsu.ac.Id/index.php/ekawan

Setiap daerah di era otonomi saat ini dituntut untuk mampu mencari, mengelola dan mengklasifikasikan potensi daerahnya sendiri. Oleh karena itu, dibutuhkan adanya suatu perencanaan pembangunan wilayah yang tepat dan sesuai dengan potensi yang dimiliki daerah itu sendiri guna mendukung percepatan pembangunan dan pertumbuhan ekonomi di daerah itu sendiri.

"Di Provinsi Sumatera Utara, terdapat satu wilayah dengan potensi alam yang sangat memukau yaitu Kabupaten Karo. Kabupaten Karo terletak pada jajaran Bukit Barisan dan sebagian besar wilayahnya merupakan dataran tinggi dengan dua gunung berapi aktif. Wilayah Kabupaten Karo berada pada ketinggian 200 - 1.500 meter di atas permukaan laut. Sebelah utara berbatasan dengan kabupaten Langkat dan kabupaten Deli Serdang, sebelah selatan dengan kabupaten Dairi dan kabupaten Samosir, sebelah timur dengan kabupaten Deli Serdang dan kabupaten Simalungun dan sebelah barat dengan propinsi Nangroe Aceh Darusalam” (Badan Pusat Statistik Kabupaten Karo, 2017).

"Dilihat dari perkembangan industri yang ada di Karo, hanya sedikit perusahaan industri besar sedang yang menyerap tenaga kerja lebih dari 100 orang, sebagian besar adalah industri kecil dan kerajinan rumah tangga yang hanya menyerap tenaga kerja 5-19 orang dan 1-4 orang. Pada umumnya membuat alat-alat yang menunjang pertanian, seperti cangkul, keranjang jeruk, makanan jadi dan lain-lain" (Purnomo, 2008).

Berikut disajikan grafik perkembangan industri di Kabupaten Karo mulai dari tahun 2010 hingga tahun 2016.

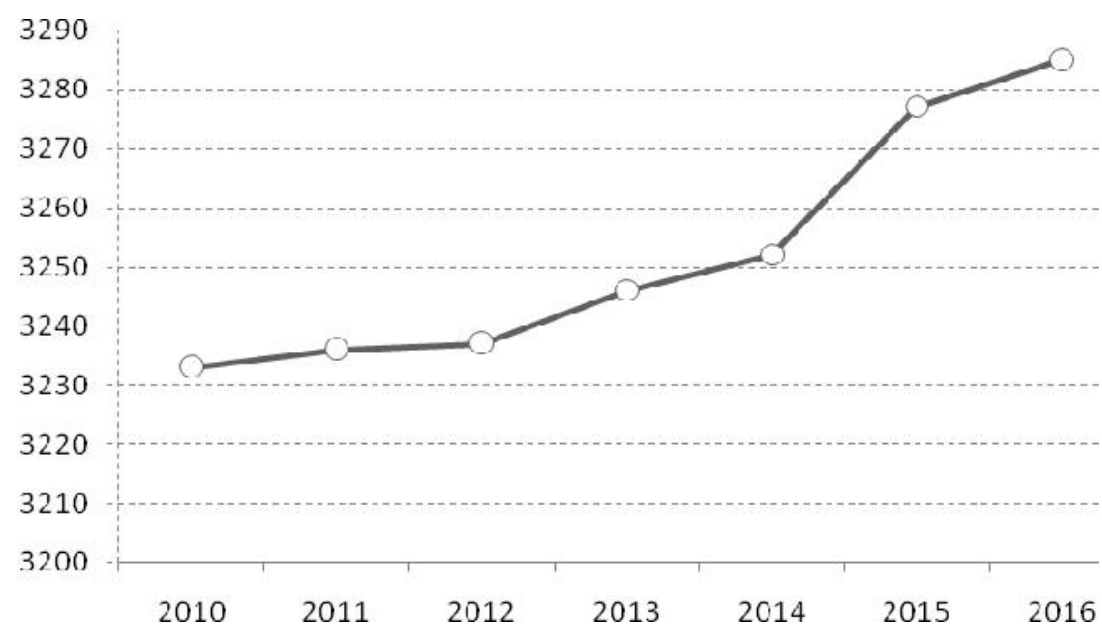

Gambar 1. Perkembangan Industri di Kabupaten Karo Tahun 2010-2016

Dari gambar 1 terlihat jumlah perusahaan industri di kabupaten Karo dari tahun 2010 sampai dengan 2016 terus mengalami peningkatan yang signifikan. Pada tahun 2010, jumlah perusahaan industri di Karo sebanyak 3.233 buah dan pada tahun 2016 sudah mencapai 3.285 buah.

Data tersebut menunjukkan adanya peluang berkembangnya perusahaan industri di Kabupaten Karo. Dengan kata lain, sektor industri tentu mempunyai kontribusi terhadap peningkatan ekonomi kabupaten Karo yaitu dapat menyerap tenaga kerja yang banyak di kabupaten Karo sehingga akan mampu menambah pendapatan masyarakatnya. 
Published July 2019

EKONOMIKAWAN : Jurnal Ilmu Ekonomi dan Studi Pembangunan

ISSN : 1693-7600 (Print), ISSN : 2598-0157 (Online), http://jurnal.umsu.ac.Id/index.php/ekawan

Seperti yang dikemukakan oleh Purnomo (2008) dalam penelitiannya yang berjudul "Analisis Peranan Sektor Industri terhadap Perekonomian Jawa Tengah tahun 2000 dan tahun 2004 (Analisis Input Output)", ia mengemukakan bahwa "sektor industri mempunyai pengaruh yang signifikan bagi perekonomian di Jawa Tengah sehingga sektor industri dijadikan sebagai sektor utama dalam perekonomian Jawa Tengah."

\section{KAJIAN TEORI}

\section{Teori Industri}

Menurut Pasaribu (2012), "istilah industri mempunyai dua arti yaitu:

a. Industri adalah himpunan perusahaan-perusahaan sejenis, misalnya industri kosmetika, berarti himpunan perusahaan-perusahaan penghasil produk-produk kosmetik. Jadi kata industri akan selalu dirangkai dengan kata yang menerangkan jenis industrinya.

b. Industri dapat pula merujuk ke suatu sektor ekonomi yang di dalamnya terdapat kegiatan produktif yang mengolah barang jadi atau barang setengah jadi. Kegiatan pengolahan tersebut dapat bersifat masinal, elektrikal atau manual. Kata lain sektor industri untuk arti yang kedua ini maksudnya adalah sektor industri pengolahan (manufacturing) yakni sebagai salah satu sektor produksi atau lapangan usaha dalam perhitungan pendapatan nasional menurut pendekatan produksi".

Sektor industri dipercaya akan mampu memimpin sektor lainnya dalam perekonomian suatu negara. Barang-barang yang dihasilkan industri diyakini mempunyai "dasar tukar (terms of trade)" yang tinggi, menguntungkan dan dapat menciptakan nilai tambah yang lebih besar jika dibandingkan dengan barang hasil sektor lainnya, karena sektor industri mempunyai bermacam-macam barang, dapat menbawa manfaat marjinal yang lebih besar bagi konsumen dan memberikan keuntungan yang lebih menarik.

Oleh sebab itu, sektor industri dianggap dapat menjadi alternatif untuk mengatasi dan membantu percepatan pembangunan ekonomi di negara berkembang. Akan tetapi, perlu diingat bahwa pengembangan sektor industri juga perlu diiringi dengan perkembangan sektor lainnya, terutama sektor pertanian bagi negara berkembang seperti di Indonesia. Sektor industri membutuhkan sektor pertanian sebagai penyedia bahan baku dan sebagai market bagi barang-barang hasil industri itu sendiri.

Adanya peningkatan daya beli petani yang semakin meningkat akan memberikan rangsangan bagi pembangunan sektor industri. Maka keberlangsungan program industrialisasi akan sangat tergantung pula pada perbaikan dan pengembangan sektorsektor lain dan seberapa besar perbaikan tersebut akan menjadi pendorong bagi munculnya industri-industri baru lainnya.

"Sektor industri merupakan komponen utama dalam pembangunan ekonomi nasional. Sektor ini tidak saja berpotensi mampu memberikan kontribusi ekonomi yang besar melalui nilai tambah, lapangan kerja dan devisa, tetapi juga mampu memberikan kontribusi yang besar dalam transformasi kultural bangsa ke arah modernisasi kehidupan masyarakat yang menunjang pembentukan daya saing nasional. Selama dua dasawarsa sebelum krisis ekonomi, peran sektor industri terhadap perekonomian nasional hampir mencapai 25\%." (Pasaribu, Rowland B. F. 2012). 
Published July 2019

EKONOMIKAWAN : Jurnal Ilmu Ekonomi dan Studi Pembangunan

ISSN : $1693-7600$ (Print), ISSN : 2598-0157 (Online), http://jurnal.umsu.ac.Id/index.php/ekawan

\section{Teori Pertumbuhan Ekonomi}

"Harrod-Domar menganalisis hubungan antara tingkat pertumbuhan ekonomi dengan investasi. Dengan melihat bahwa pada suatu tingkat pendapatan nasional tertentu yang cukup untuk menyerap seluruh tenaga kerja dengan tingkat upah di satu periode maka pada periode berikutnya tidak akan mampu lagi untuk menyerap seluruh tenaga kerja yang tersedia, sehingga untuk menumbuhkan perekonomian diperlukan investasi baru sebagai tambahan modal yang digunakan untuk mencapai tingkat penyerapan tenaga kerja yang penuh pada periode berikutnya." (Riyad, Mohamad. 2012).

Jadi menurut Harrod-Domar, dalam proses pertumbuhan ekonomi, investasi mempunyai peranan utama karena investasi dengan cara persediaan modal ditingkatkan bisa meningkatkan pendapatan dan memperbesar kapasitas produksi perekonomian. Karenanya, selama investasi masih tersedia dan tetap berlangsung maka produksi dan pendapatan riil akan terus meningkat. Namun, pendapatan riil dan output harus dalam laju yang sama pada kapasitas produktif kapital yang meningkat untuk menjaga pendapatan keseimbangan pada kondisi full employment. Jika tidak, maka setiap perbedaan kuantitas pada masing-masing variabel akan menimbulkan kelebihan kapasitas (idle capacity). Dan dampaknya akan mengakibatkan pengeluaran investasinya dibatasi oleh pengusaha dan dapat berdampak negatif bagi perekonomian yaitu akan mengakibatkan penurunan pendapatan dan kesempatan kerja pada masa akan datang, yang akhirnya perekonomian akan bergeser keluar dari jalur pertumbuhannya.

"Dalam model pertumbuhan Harrod-Domar tersebut terlihat bahwa steady state sangat tidak stabil. Apabila rasio tabungan, rasio kapital output, dan laju kenaikan tenaga kerja meleset sedikit saja, maka akibatnya akan berupa inflasi atau meningkatnya pengangguran. Kemudian Solow memperbaiki model pertumbuhan yang disampaikan Harrod-Domar tersebut. Solow mengatakan bahwa rasio kapital output dalam model Harrod-Domar tersebut tidak bisa dianggap sebagai eksogenus, karena dalam kenyataannya rasio kapital output tersebut merupakan adjusting variable yang akan menggiring kembali sistem pada jalur pertumbuhan steady state" (Riyad, Mohamad. 2012).

\section{METODE}

\section{Sumber Data}

Jenis data dalam penelitian ini adalah data sekunder yaitu jumlah perusahaan industri dan tingkat pertumbuhan ekonomi kabupaten Karo dari tahun 2010-2016. Data diperoleh dari laporan statistik tahunan Badan Pusat Statistik kabupaten Karo.

\section{Variabel Penelitian}

Variabel yang digunakan dalam penelitian ini yaitu variabel independen dan variabel dependen. Yang menjadi variabel independen yaitu variabel jumlah perusahaan industri $\left(\mathrm{X}_{1}\right)$ Sementara yang menjadi variabel dependen yaitu pertumbuhan ekonomi kabupaten Karo (Y).

\section{Teknik Analisis Data}

"Analisis regresi yang digunakan adalah regresi linier sederhana. Persamaan umum untuk model regresi linier sederhana yaitu:

$$
\mathbf{Y}=\mathbf{a}+\mathbf{b X}
$$


Model regresi linier sederhana dapat dikatakan baik jika sudah memenuhi syarat BLUE yaitu bebas dari gejala uji asumsi klasik yaitu uji normalitas, multikolinearitas, heteroskedastisitas dan autokorelasi.

\section{Uji Asumsi Multikolinieritas}

"Tujuan digunakannya uji ini adalah untuk menguji apakah pada model regresi ditemukan adanya korelasi antar variabel independen. Jika terdapat atau terjadi korelasi, maka dinamakan terdapat masalah multikolinieritas. Model regresi yang baik seharusnya tidak terjadi korelasi di antara variabel independen." (Gujarati, 2004).

\section{Uji Asumsi Autokorelasi}

"Uji autokorelasi bertujuan untuk menguji apakah dalam model regresi linear ada korelasi antara kesalahan pengganggu pada periode $t$ dengan kesalahan pengganggu pada periode sebelumnya. Jika terjadi korelasi, maka terjadi gejala autokorelasi." (Gujarati, 2004).

\section{Uji Asumsi Heteroskedastisitas}

"Uji ini bertujuan untuk menguji apakah dalam model regresi terjadi atau terdapat ketidaksamaan varians dari residual dari satu pengamatan ke pengamatan yang lain. Jika varians dari nilai residual dari satu pengamatan ke pengamatan yang lain tetap, maka disebut dengan Homokedastisitas. Dan jika varians berbeda dari satu pengamatan ke pengamatan yang lainnya, maka disebut heteroskedastisitas. Model regresi yang baik adalah yang tidak terjadi heteroskedastisitas, atau dengan kata lain model regresi yang baik adalah yang homokedastisitas." (Gujarati, 2004)

\section{Uji Asumsi Normalitas}

"Uji ini bertujuan untuk menguji apakah dalam sebuah model regresi, variabel independen, variabel dependen, atau keduanya mempunyai distribusi normal atau tidak. Suatu model regresi yang baik adalah yang memiliki distribusi data normal atau mendekati normal" (Gujarati, 2004).

\section{HASIL DAN PEMBAHASAN}

\section{Uji Asumsi Klasik}

\section{Uji Multikolinearitas}

Hasil dari uji multikolinieritas dapat dilihat dalam tabel 1 berikut ini:

Tabel 1. Hasil Uji Multikolinieritas

\begin{tabular}{|c|c|cc|}
\hline \multicolumn{2}{|c|}{ Model } & \multicolumn{2}{c|}{$\begin{array}{c}\text { Collinearity Statistic } \\
\text { Tolerance }\end{array}$} \\
VIF \\
\hline 1 & $\begin{array}{c}\text { (Constant) } \\
\text { X }\end{array}$ & 1,000 & 1,000 \\
\hline
\end{tabular}

Dari tabel 1 tersebut menunjukkan bahwa variabel bebas tidak memiliki nilai Tolerance yang kurang dari 0,100, artinya tidak ada korelasi antar variabel bebas sehingga dapat disimpulkan bahwa tidak terjadi gejala multikolinearitas. 
Published July 2019

EKONOMIKAWAN : Jurnal Ilmu Ekonomi dan Studi Pembangunan

ISSN : 1693-7600 (Print), ISSN : 2598-0157 (Online), http://jurnal.umsu.ac.Id/index.php/ekawan

\section{Uji Asumsi Autokorelasi}

Uji autokorelasi ini dilakukan untuk menguji apakah dalam model regresi linear ada korelasi antara kesalahan penganggu pada periode $\mathrm{t}$ dengan kesalahan penganggu pada periode sebelumnya, yang bisa dilihat pada tabel 2 berikut ini:

Tabel 2. Hasil Uji Autokorelasi

\begin{tabular}{|c|r|r|}
\hline Model & Std. Error of the Estimate & Durbin-Watson \\
\hline 1 & 409380.32019 & 1.425 \\
\hline
\end{tabular}

Nilai DW pada tabel sebesar 1,425 akan dibandingkan dengan nilai tabel dengan signifikansi 5\%, jumlah sampel 7 dan jumlah variabel independen 1. Oleh karena nilai 1,425 lebih besar dari batas atas (du) 1,3564 dan kurang dari 4-du, maka dapat disimpulkan bahwa tidak terdapat autokorelasi.

\section{Uji Asumsi Heteroskedastisitas}

Uji ini bertujuan untuk menguji apakah dalam model regresi terdapat ketidaksamaan varians dari residual dari suatu pengamatan ke pengamatan yang lain.

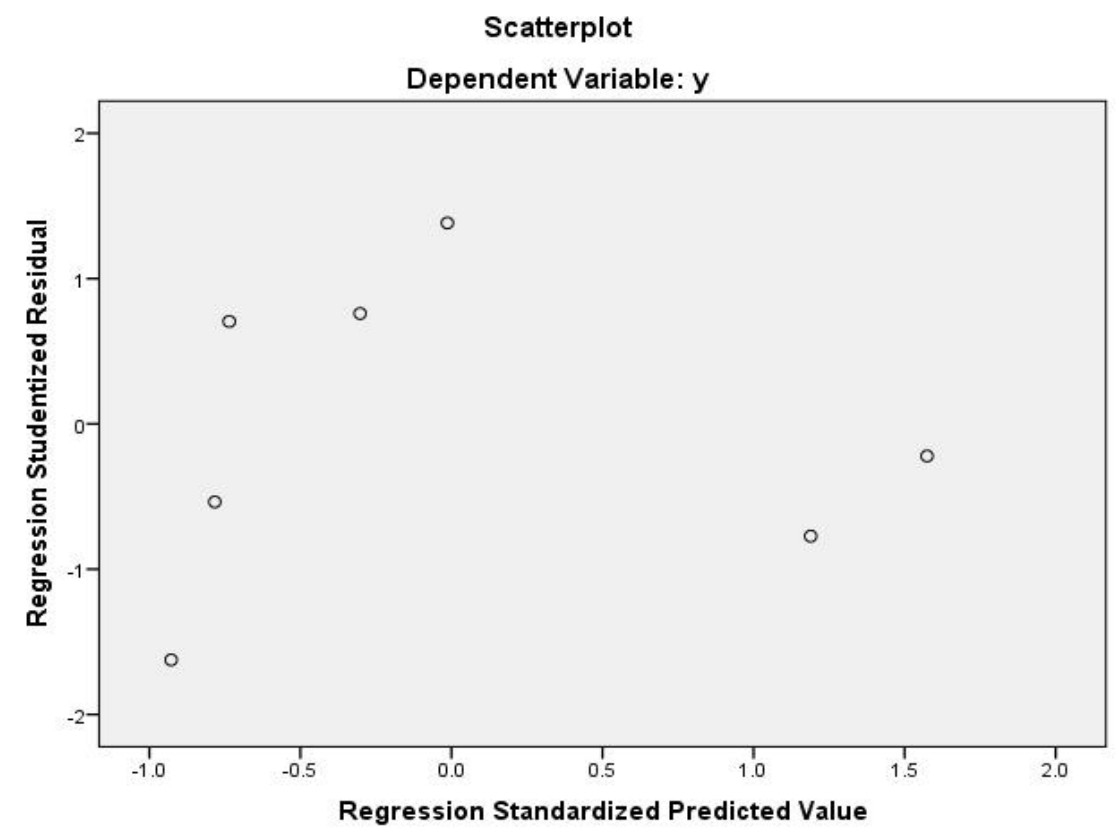

Gambar 2. Hasil Uji Heteroskedastisitas

Dari grafik Scatterplot pada gambar 2 tampak bahwa titik-titik menyebar secara acak dan tersebar baik di atas maupun di bawah angka nol pada sumbu Y. Sehingga model pada penelitian ini memenuhi syarat untuk menjadi model yang baik karena merupakan model yang homoskedastisitas. 
Published July 2019

EKONOMIKAWAN : Jurnal Ilmu Ekonomi dan Studi Pembangunan

ISSN : $1693-7600$ (Print), ISSN : 2598-0157 (Online), http://jurnal.umsu.ac.ld/index.php/ekawan

\section{Uji Asumsi Normalitas}

Hasil dari uji normalitas ini dapat dilihat dalam gambar 3 berikut ini.
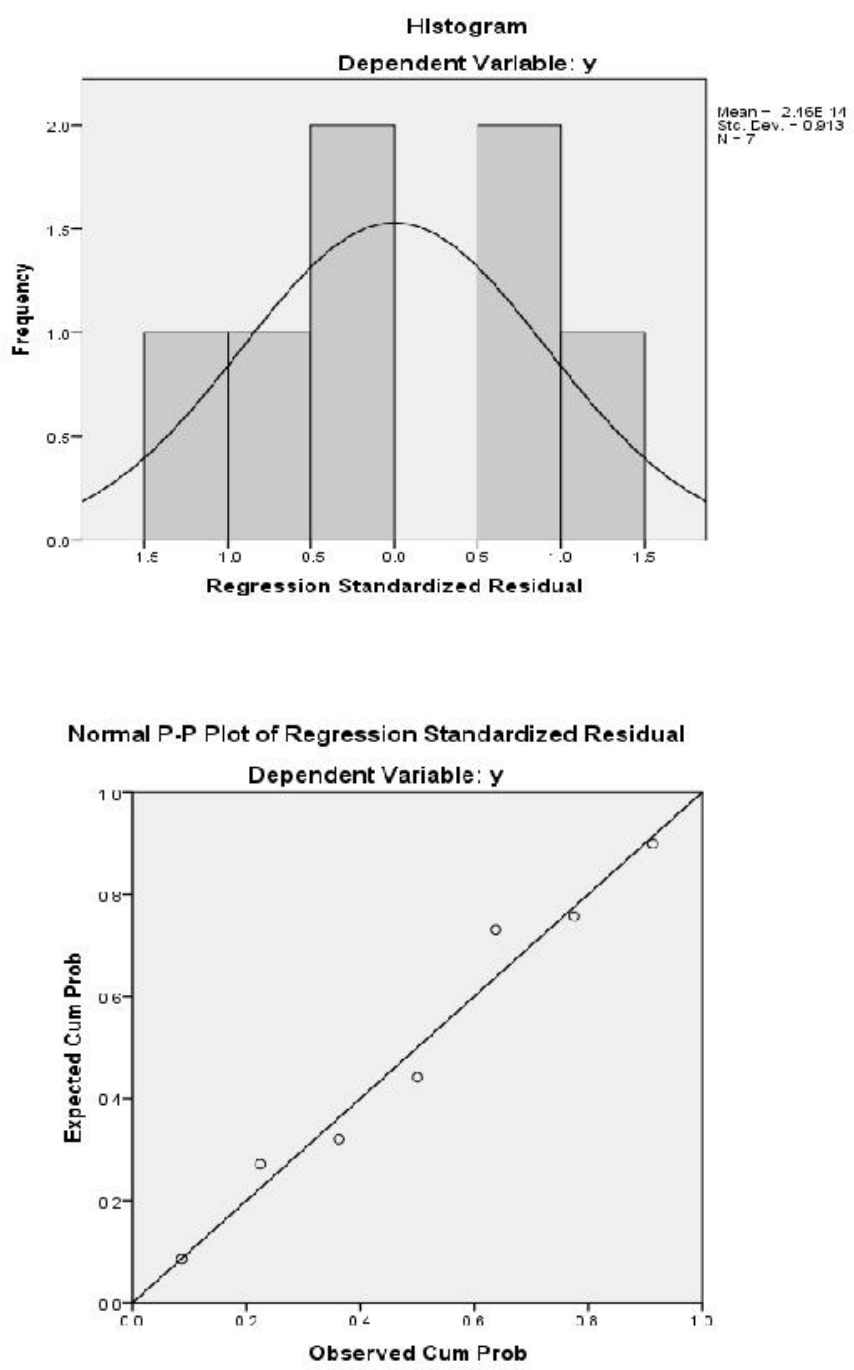

Gambar 3. Hasil Uji Normalitas

Grafik histogram memberikan pola distribusi yang normal. Sedangkan pada grafik normal plot, terlihat titik-titik menyebar di sekitar garis diagonal yang menunjukkan bahwa model regresi tidak menyalahi asumsi normalitas. Sehingga dapat disimpulkan bahwa pada model regresi ini memenuhi syarat untuk menjadi model regresi yang baik karena memenuhi syarat uji normalitas.

\section{Uji Statistik}

1. Koefisien Determinasi $\left(\mathbf{R}^{2}\right)$

Koefisien Determinasi atau $\mathrm{R}^{2}$ menunjukkan besarnya kontribusi dari jumlah perusahaan industri terhadap pertumbuhan ekonomi di kabupaten Karo. Dapat dilihat pada tabel 3 dibawah ini : 
Published July 2019

EKONOMIKAWAN : Jurnal Ilmu Ekonomi dan Studi Pembangunan

ISSN : $1693-7600$ (Print), ISSN : 2598-0157 (Online), http://jurnal.umsu.ac.ld/index.php/ekawan

Tabel 3. Hasil Uji Koefisien Determinasi

\begin{tabular}{|l|r|r|r|r|}
\hline Model & R & R Square & $\begin{array}{r}\text { Adjusted } \\
\text { R Square }\end{array}$ & $\begin{array}{r}\text { Std. Error of } \\
\text { the Estimate }\end{array}$ \\
\hline 1 & $.947^{\mathrm{a}}$ & .897 & .877 & $\begin{array}{r}409380.320 \\
19\end{array}$ \\
\hline
\end{tabular}

Nilai R-squared yaitu 0,947 yang artinya adalah kemampuan variabel jumlah perusahaan industri dalam menjelaskan pertumbuhan ekonomi di kabupaten Karo adalah sebesar $94,7 \%$ dan sisanya sebesar 5,3\% dijelaskan oleh variabel lain diluar model estimasi.

\section{Uji Simultan (Uji-F)}

Uji F digunakan untuk menguji apakah semua variabel bebas yang digunakan memiliki pengaruh simultan terhadap variabel terikat, yang dapat dilihat pada tabel 4 .

Tabel 4. Hasil Uji Simultan

\begin{tabular}{|c|c|c|c|}
\hline \multicolumn{2}{|c|}{ Model } & F & Sig \\
\hline \multirow{2}{*}{1} & Regression & 43.631 & $.001^{\mathrm{b}}$ \\
\cline { 2 - 4 } & Residual & & \\
\cline { 2 - 4 } & Total & & \\
\hline
\end{tabular}

Hasil dari uji simultan (uji F), nilai probabilitas F-statistik adalah 0,001 dan lebih kecil dari $\alpha=0,05$ sehingga $\mathrm{H}_{0}$ ditolak artinya variabel jumlah industri secara simultan berpengaruh positif dan signifikan terhadap pertumbuhan ekonomi kabupaten Karo.

\section{Hasil Uji Parsial (Uji-t)}

Uji t digunakan untuk menguji apakah masing-masing variabel independen memiliki pengaruh secara parsial dan signifikan terhadap variabel terikatnya, yang dapat dilihat pada tabel 5.

Tabel 5. Hasil Uji Parsial (Uji-t)

\begin{tabular}{|c|c|c|c|c|c|}
\hline \multirow{2}{*}{\multicolumn{2}{|c|}{ Model }} & \multicolumn{2}{|c|}{ Unstandardized Coefficients } & \multirow[b]{2}{*}{$\mathrm{t}$} & \multirow[b]{2}{*}{ Sig. } \\
\hline & & B & Std. Error & & \\
\hline \multirow[t]{2}{*}{1} & (Constant) & -161943066.859 & 26154934.179 & -6.192 & .002 \\
\hline & $\mathrm{X}$ & 53119.718 & 8041.875 & 6.605 & .001 \\
\hline
\end{tabular}

Nilai koefisien variabel jumlah industri adalah 53119.718 dengan probabilitas sebesar 0.001 , yang artinya variabel jumlah industri berpengaruh positif dan signifikan terhadap pertumbuhan ekonomi Kabupaten Karo. 
Published July 2019

EKONOMIKAWAN : Jurnal Ilmu Ekonomi dan Studi Pembangunan

ISSN : 1693-7600 (Print), ISSN : 2598-0157 (Online), http://jurnal.umsu.ac.Id/index.php/ekawan

\section{Pengaruh Aktivitas Industri terhadap Pertumbuhan Ekonomi Kabupaten Karo}

Hasil uji statistik menunjukkan bahwa jumlah perusahaan industri berdampak positif dan signifikan terhadap pertumbuhan ekonomi Kabupaten Karo. Dengan kata lain, semakin banyak jumlah perusahaan industri maka akan berdampak positif pula bagi perkembangan pertumbuhan ekonomi kabupaten Karo.

Dampak positif ini dipicu karena dengan adanya perusahaan industri maka tenaga kerja di kabupaten Karo akan terserap sehingga akan berdampak pada peningkatan pendapatan masyarakatnya. Peningkatan pendapatan akan mendorong peningkatan kesejahteraan masyarakat dan akan berdampak meningkatnya pertumbuhan ekonomi di kabupaten Karo.

Hal ini sejalan dengan penelitian yang dilakukan oleh Napitupulu (2016). Dalam penelitiannya, ia menemukan bahwa "Kota Batam sebagai salah satu kota yang letaknya strategis di provinsi Kepulauan Riau memiliki kebijakan yang mendukung pengembangan sektor industri. Pengaruh aktivitas industri di kota Batam terhadap peningkatan ekonomi penduduk, khususnya yang bekerja di sektor industri cukup besar."

Adanya aktivitas industri di kota Batam memberikan dampak yang positif pada berbagai bidang, khususnya penghasilan masyarakat yang mengalami peningkatan. Setelah ditetapkan sebagai kota industri, adanya aktivitas perusahaan industri menjadi nilai tambah bagi masyarakat terutama dalam meningkatkan kesejahteraan hidupnya.

Keberadaan industri yang berdampak positif inilah yang menyebabkan antusiasme dari masyarakat untuk bekerja di perusahaan industri. Adanya kesesuaian pendapatan menjadi jaminan bahwa kegiatan industri sangat berpengaruh positif bagi masyarakat yang bekerja di perusahaan industri.

Sholihah (2017) dalam penelitiannya menunjukkan bahwa "investasi industri manufaktur secara simultan dipengaruhi oleh suku bunga (SB), nilai tukar (NT) dan penyerapan tenaga kerja industri manufaktur (PTK). Investasi tersebut digunakan sebagai salah satu komponen pembangunan perekonomian suatu wilayah karena melalui investasi, kapasitas produksi dapat ditingkatkan yang kemudian mampu meningkatkan output, yang akhirnya juga akan meningkatkan pertumbuhan ekonomi dan penyerapan tenaga kerja sektor industri manufaktur di Indonesia."

Pendapat yang sama juga dikemukakan oleh Zuliastri (2013). Dalam penelitiannya, ia mengemukakan bahwa "Pembangunan sektor industri merupakan bagian dari pembangunan ekonomi jangka panjang karena kontribusi sektor industri yang sangat besar terhadap pembentukan Produk Domestik Bruto (PDB) yaitu 25,60 \% khususnya industri non migas 23,86\% pada tahun 2012".

Pengembangan industri berbasis unggulan daerah menjadi salah satu cara yang dapat digunakan pemerintah daerah untuk terus meningkatkan daya saing industri secara nasional. Potensi daerah yang dimiliki jika dikombinasikan dengan pendekatan aglomerasi maka industri unggulan tersebut akan terus berkembang dan menarik munculnya industriindustri baru lainnya sehingga dapat meningkatkan pertumbuhan industri daerah dan pendapatan daerah tersebut. 
Published July 2019

EKONOMIKAWAN : Jurnal Ilmu Ekonomi dan Studi Pembangunan

ISSN : 1693-7600 (Print), ISSN : 2598-0157 (Online), http://jurnal.umsu.ac.Id/index.php/ekawan

Mukhlis (2014) juga mengemukakan bahwa "Pengembangan ekonomi lokal merupakan usaha daerah dalam memacu pembangunan ekonominya dan diharapkan dapat memberikan manfaat bagi masyarakat keseluruhan secara luas. Pengembangan ekonomi lokal sendiri merupakan penumbuhan suatu lokalitas secara lebih mandiri dengan menggunakan potensi kekuatan lokal, sumber daya manusia, kelembagaan dan fisik dengan upaya yang ditumbuhkembangkan masyarakat lokal itu sendiri."

Peran dan kebijakan dari Pemerintah Daerah akan sangat menentukan pengembangan UKM sehingga bisa melindungi UKM dengan meningkatkan efisiensi dan produktivitas birokrasi pemerintah, melakukan pembenahan kelembagaan serta koordinasi antara instansi terkait dan meningkatkan peran serta pengusaha UKM dalam pembangunan di kabupaten Karo.

\section{SIMPULAN}

Aktivitas industri memiliki pengaruh positif dan signifikan terhadap pertumbuhan ekonomi kabupaten Karo.

\section{DAFTAR PUSTAKA}

Pasaribu, Rowland B. F. 2012. Bahan Ajar Perekonomian Indonesia. Kenari: Fakultas Ekonomi Universitas Gunadarma.

Syaifullah. 2009. Industrialisasi, Manusia Industri dan Perubahan Sosial. Jurnal GeografiGEA. Vol. 9 No.1, hlm. 39-50.

Nawawi, Imam, Yadi Ruyadi, Siti Komariah. 2014. Pengaruh Keberadaan Industri terhadap Kondisi Sosial Ekonomi dan Budaya Masyarakat Desa Lagadar Kecamatan Marga Asih Kabupaten Bandung. Jurnal Sosietas, Vol. 5, No. 2, hlm. 40-53.

Badan Pusat Statistik Kabupaten Karo 2017. Karo dalam Angka 2017. Karo.

http://karokab.bps.go.id (diakses pada tanggal 01 Februari 2019).

Purnomo, Didit dan Devi Istiqomah. 2008. Analisis Peranan Sektor Industri terhadap Perekonomian Jawa Tengah tahun 2000 dan tahun 2004 (Analisis Input Output). Jurnal Ekonomi Pembangunan Vol. 9, No.2, hlm.137-155.

Riyad, Mohamad. 2012. Faktor-faktor yang Mempengaruhi Pertumbuhan Ekonomi di Enam Negara ASEAN Tahun 1990-2009. Jakarta: Fakultas Ekonomi UI.

Gujarati. 2004. Basic Econometrics. New York: Mc Gwra Hill, Inc.

Napitupulu, B. K. dan P. Nugroho. 2016. Pengaruh Aktivitas Industri terhadap Peningkatan Ekonomi Penduduk dan Perkembangan Perdagangan dan Jasa di Kota Batam. Jurnal Teknik PWK, Vol.5, No.1, hlm.1-9.

Sholilah, Irma Mar'atus, Syaparuddin dan Nurhayani. 2017. Analisis Investasi Sektor Industri Manufaktur, Pengaruhnya terhadap Pertumbuhan Ekonomi dan Penyerapan Tenaga Kerja di Indonesia. Jurnal Paradigma Ekonomika, Vol.12, No.1, hlm.23-34.

Zuliastri, Fikanti, Wiwiek Rindayati dan Alla Asmara. 2013. Analisis Faktor yang Mempengaruhi Aglomerasi Industri Unggulan Daerah dan Hubungannya dengan Daya Saing Industri Daerah. Jurnal Ekonomi dan Kebijakan Pembangunan, Vol.2 No.2, hlm.113-134.

Mukhlis, Dirta Pratama Atiyatna dan Nabila Dehannisa. 2014. Pengembangan Ekonomi Lokal Kota Palembang melalui Kajian Potensi Klaster Industri Kecil: Pendekatan Tipology Klassen. Jurnal Ekonomi Pembangunan, Vol. 12, No. 2, hlm. 67-80. 